\title{
ANALISA POTENSI AKUIFER DI KECAMATAN RUMBAI PESISIR KOTA PEKANBARU DENGAN MENGGUNAKAN METODE GEOLISTRIK ATURAN SCHLUMBERGER
}

\author{
Riad Syech, Miftakhudin Listianto* \\ Jurusan Fisika Fakultas Matematika dan Ilmu Pengetahuan Alam Universitas Riau \\ *E-mail korespondensi: imieftheexpendable@gmail.com
}

\begin{abstract}
The analysis of aquifer potential has been done in the Rumbai Pesisir District of Pekanbaru City by using the Schlumberger configuration geoelectric method. Data was taken from four villages in Rumbai Pesisir Subdistrict, in Lembah Damai, Limbungan, Limbungan Baru and Meranti Pandak. The result obtained using progress software showed that each location has aquifer with different layer and thickness. The highest aquifer resistivity is located in Lembah Damai Village with a resistivity value of $549.50 \Omega m$ in the third layer, while aquifer with the lowest resistivity value is located in Meranti Pandak Village with a resistivity value of $15.69 \mathrm{\Omega m}$ in the third layer. The highest thickness aquifer located in Meranti Pandak Village with a thickness of $48.47 \mathrm{~m}$ in the third layer, while the lowest thickness aquifer located in Limbungan Baru Village with a thickness of $11.51 \mathrm{~m}$ in the second layer. The Result from lithology of each path shows that flow pattern of water flowing from Lembah Damai Village to Limbungan Village, then Meranti Pandak Village and then Limbungan Baru Village. The results of the analysis of aquifers potential indicate that underground water reserves in the Rumbai Pesisir District of Pekanbaru City are $17.13 \times 10^{9} \mathrm{~m}^{3}$.
\end{abstract}

Keywords: Groundwater, Geoelectric Method, Schlumberger Configuration, Resistivity, Aquifer Potential

\begin{abstract}
ABSTRAK
Analisa potensi akuifer di Kecamatan Rumbai Pesisir Kota Pekanbaru telah dilakukan menggunakan metode geolistrik aturan schlumberger. Data diambil dari empat Kelurahan di Kecamatan Rumbai Pesisir yaitu Kelurahan Lembah Damai, Limbungan, Limbungan Baru dan Meranti Pandak. Hasil yang diperoleh dari software progress menunjukkan setiap lokasi memiliki akuifer dengan lapisan dan ketebalan yang berbeda. Resistivitas akuifer tertinggi terletak di Kelurahan Lembah Damai dengan nilai resistivitas 549,50 $\Omega$ m berada pada lapisan ketiga, sedangkan akuifer dengan nilai resistivitas terendah terletak di Kelurahan Meranti Pandak dengan nilai resistivitas 15,69 $\Omega$ m berada pada lapisan ketiga. Akuifer dengan ketebalan tertinggi berada di Kelurahan Meranti Pandak dengan ketebalan 48,47 m pada lapisan ketiga, sedangkan akuifer dengan ketebalan terendah berada di Kelurahan Limbungan Baru dengan ketebalan 11,51 m berada pada laisan kedua. Hasil dari litologi tiap lintasan menunjukkan pola aliran air mengalir dari Kelurahan Lembah Damai menuju Kelurahan Limbungan lalu Kelurahan Meranti Pandak dan ke Kelurahan Limbungan Baru. Analisa potensi akuifer menunjukkan cadangan air bawah tanah di Kecamatan Rumbai Pesisir Kota Pekanbaru adalah 17,13 $x 10^{9}$ $m^{3}$.
\end{abstract}

Kata kunci: Air Tanah, Metode Geolistrik, Konfigurasi Schlumberger, Resistivitas, Potensi Akuifer

Diterima 10-01-2020| Disetujui 15-02-2020| Dipublikasi 31-03-2020

\section{PENDAHULUAN}

Keseimbangan antara ketersediaan dan kebutuhan baik secara kuantitas maupun kualitas terhadap air tanah di Kota Pekanbaru semakin kritis. Kesemuanya ini di sebabkan karena pertumbuhan penduduk di Kota Pekanbaru yang sangat tinggi, serta 
pembangunan yang menyebabkan timbulnya polusi serta berkurangnya lahan ruang hijau untuk proses pembentukan air tanah [1].

Masyarakat Kota Pekanbaru terutama di kecamatan Rumbai Pesisir kesulitan memanfatkan air permukaan karena adanya pencemaran air sungai siak. Dampak pencemaran air sumgai membuat air permukaan sumur dangkal ikut tercemar [2].

Pencemaran sumur dangkal dapat diakibatkan Karena umumnya struktu geologi Kota pekanbaru sepanjang pesisir sungai siak adalah aluvium rawa atau lumpur [4]. Lumpur adalah campuran cair atau semi cair antara air dan tanah. Lumpur terjadi pada saat tanah menjadi basah. Secara geologis, lumpur ialah campuran air dan partikel endapan lumpur dan tanah liat [3].

Masyarakat dan industri di Kecamatan Rumbai Pesisir Kota Pekanbaru memilih untuk memanfaatkan air bawah tanah. Kelebihan air bawah tanah dibandingkan air permukaan adalah air bawah tanah tidak mudah tercemar. Pemanfaatan dan pengelolaan daerah pesisir yang dilakukan oleh masyarakat maupun daerah sebagian belum memenuhi ketentuan pemanfaatan sumber daya air bawah tanah secara lestari dan berkelanjutan. Hal ini akan berpengaruh terhadap kondisi dan kelestarian pesisir dan lingkungannya. Penyebab degradasi kondisi daerah pesisir secara tidak langsung juga disebabkan oleh pengelolaan sumber daya alam di hulu yang berpengaruh terhadap muara di pesisir, misalnya akibat ekploitasi air bawah tanah yang berlebihan oleh industri - industri [5].

Berbagai aktivitas dapat mempengaruhi kondisi akuifer yaitu kegiatan industri, domestik, pertanian, peternakan, fasilitas umum dan perkantoran. Semua aktivitas di Kecamatan Rumbai Pesisir harus tetap berjalan dan bahkan harus meningkat, namun aktivitas - aktivitas tersebut mesti berwawasan lingkungan dan tetap menjamin keberlanjutan sistem akuifer yang ada di Rumbai Pesisir. Hal ini berarti kegiatan pembangunan tetap berjalan namun kemampuan daya dukung lingkungan utamanya berupa lingkungan air bawah tanah harus dapat ditingkatkan. Seiring dengan perkembangan dan pembangunan di Kawasan Kecamatan Rumbai Pesisir, akan mendorong meningkatnya kebutuhan air bersih. Hal ini berpengaruh terhadap berkurangnya daya dukung lingkungan utamanya karena berkurangnya imbuhan air bawah tanah.

Kandungan air yang terdapat di akuifer akan meningkat pada musim hujan sedangkan pada musim kemarau kandungan air yang terdapat di akuifer menurun atau tidak ada sama sekali. Sistem potensi akuifer bebas di dalam tanah sangat rumit keberadaannya, namun dapat dipelajari dan diprediksi keberadaannya. Keberlanjutan dan daya dukung air bawah tanah diketahui dengan menganalisa potensi cadangan air bawah tanah di Kecamatan Rumbai Pesisir Kota Pekanbaru.

\section{METODE PENELITIAN}

Penelitian ini menggunakan metode eksperimen lapangan, proses pengukuran lapangan untuk mendapatkan data biofisik yang berupa data primer seperti nilai potensial serta arus pada resistivitymeter dan data sekunder berupa koordinat lokasi menggunakan GPS. Data diambil di empat Kelurahan yang tersebar di Kecamatan Rumbai Pesisir yaitu Kelurahan Lembah damai, Kelurahan Limbungan, Kelurahan Limbungan Baru, dan Kelurahan Meranti Pandak.

Langkah pertama adalah dengan mengukur panjang lintasan yang akan diteliti. Menentukan titik tengah dari panjang lintasan sebagai titik acuan dimulainya pengukuran. Menghubungkan kabel-kabel pada elektroda arus dan elektroda potensial dan menghubungkannya pada alat resistivitymeter. Menancapkan elektroda arus dan elektroda potensial ditanah dengan kedalaman $15 \mathrm{~cm}$. Mengatur jarak elektroda, yakni jarak elektroda potensial (MN) adalah sebesar empat meter dan jarak elektroda arus (AB) adalah sebesar delapan meter. Hubungkan alat resistivitymeter ke Aki, kemudian catat hasil 
awalnya. Pindahkan masing-masing elektroda potensial sejauh dua meter dan masing-masing elektroda arus sejauh empat meter sampai dengan panjang lintasan yang diukur selesai. akukan pengambilan data di titik selanjutnya dengan langkah yang sama pada titik pertama dengan mengatur spasi antara elektroda arus dan elektroda potensial. Setelah melakukan penelitian, hasil yang kita dapat akan diolah menggunakan software progres. Nilai elektroda arus, nilai elektroda potensial, kuat arus dan tegangan yang didapat dari hasil pengukuran diolah dengan menggunakan program Excel untuk mengetahui nilai resistivitas dan faktor geometrinya. Data yang telah diolah menggunakan program Excel tadi kemudian di input ke software progress dengan memasukan nilai $\mathrm{AB} / 2$ dan nilai resistivitasnya. Setelah diolah menggunakan software progress maka akan muncul struktur litologi lapisan bawah tanah serta nilai resistivitas dan ketebalan pada setiap lapisan. Dari nilai tersebut kita dapat menentukan potensi air bawah tanahnya. Analisa potensi air bawah tanah dapat di ketahui dengan cara menghitung volume lapisan yang dapat menyimpan maupun mengalirkan air bawah tanah, yaitu lapisan akuifer. Jumlah cadangan air bawah tanah didapat dengan mengalikan ketebalan lapisan akuifer terhadap luas wilayah terbuka suatu daerah.

\section{HASIL DAN PEMBAHASAN}

Data interpretasi geolistrik dari empat lintasan di paparkan sebagai berikut

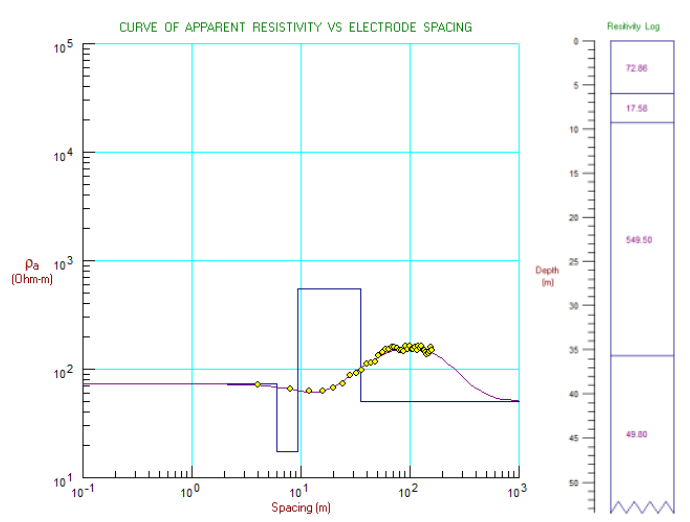

Gambar 1. Kurva dan lapisan Lintasan 1.

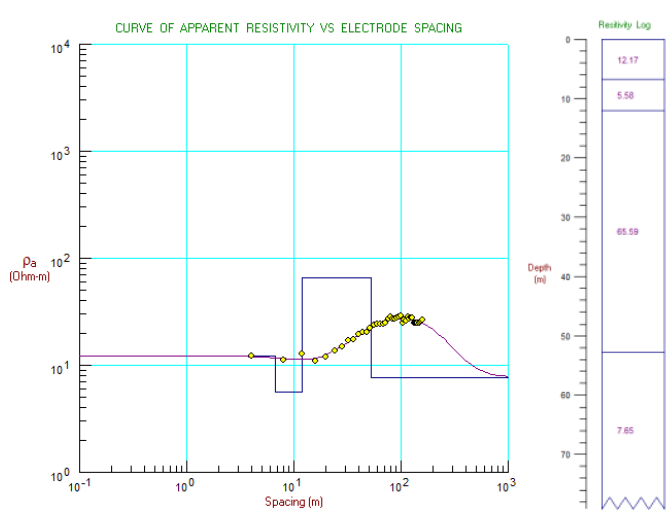

Gambar 2. Kurva dan lapisan Lintasan 2.

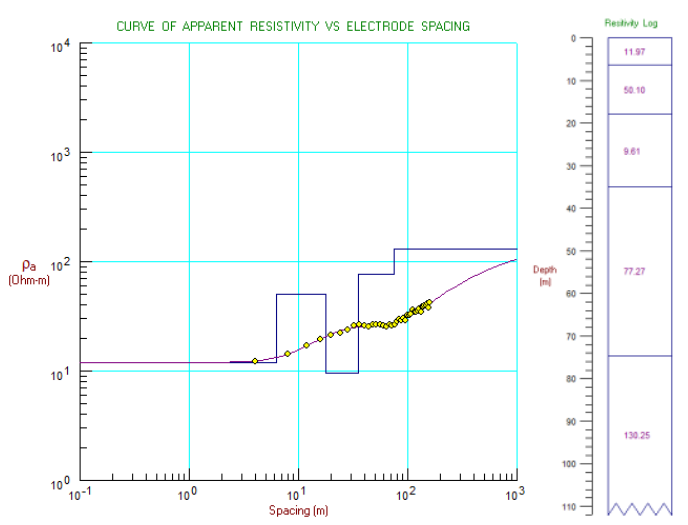

Gambar 3. Kurva dan lapisan Lintasan 3.

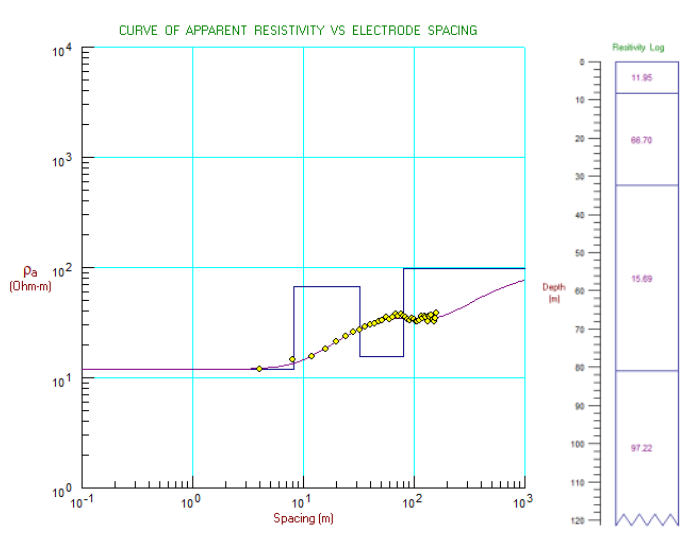

Gambar 4. Kurva dan lapisan Lintasan 4.

Data interpretasi lintasan 1 menunjukan terdapat 4 lapisan litologi, dimana lapisan akuifer terletak pada lapisan ke 3 memiliki nilai resistifitas $549,50 \Omega \mathrm{m}$ dengan ketebalan $26,38 \mathrm{~m}$. Data interpretasi lintasan 2 menunjukan terdapat 4 lapisan litologi, dimana lapisan akuifer terletak pada lapisan ke 3 memiliki nilai resistifitas $65,59 \Omega \mathrm{m}$ dengan ketebalan 40,78 m. Data interpretasi lintasan 3 menunjukan terdapat 5 lapisan litologi, dimana 
lapisan akuifer terletak pada lapisan ke 2 memiliki nilai resistifitas $50,10 \Omega \mathrm{m}$ dengan ketebalan 11,51 m. Data interpretasi lintasan 4 menunjukan terdapat 4 lapisan litologi, dimana lapisan akuifer terletak pada lapisan ke memiliki nilai resistifitas $15,69 \Omega \mathrm{m}$ dengan ketebalan 48,47 m.

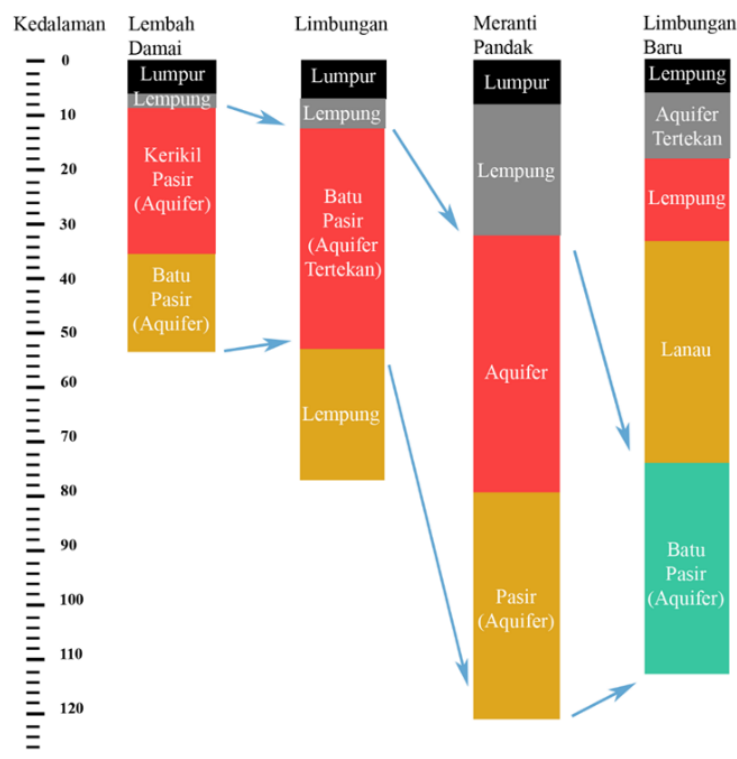

Gambar 5. Kedalaman lapisan bawah permukaan.

Data dari litologi akuifer tiap lintasan menunjukkan pola aliran air mengalir dari Kelurahan Lembah Damai menuju Kelurahan Limbungan lalu Kelurahan Meranti Pandak dan ke Kelurahan Limbungan Baru. Potensi air bawah tanah dapat dihitung dengan mengalikan ketebalan lapisan akifer dengan luas wilayah ruang terbuka suatu daerah. adapun luas wilayah terbuka kecamatan rumbai pesisir adalah $134,75 \times 10^{6} \mathrm{~m}^{2}$ dan ketebalan akuifer tiap lintasan adalah 26,38 m, $40,78 \mathrm{~m}, 11,51 \mathrm{~m}$, dan 48,47 m. Jumlah total cadangan air bawah tanah Kecamatan Rumbai Pesisir adalah $17,13 \times 10^{9} \mathrm{~m}^{3}$.

\section{KESIMPULAN}

Berdasarkan penelitian yang telah dilakukan dapat disimpulkan bahwa pola aliran mengalir dari Kelurahan Lembah Damai menuju Kelurahan Limbungan lalu Kelurahan Meranti Pandak dan ke Kelurahan Limbungan Baru. Jumlah total cadangan air bawah tanah Kecamatan Rumbai Pesisir adalah 17,13 x 109 $\mathrm{m}^{3}$.

\section{DAFTAR PUSTAKA}

1. Juandi, M. (2014). Model Head Hydrolic Akuifer Bebas Kondisi Unsteady State. Komunikasi Fisika Indonesia, 11(9), 612627.

2. Neyamadpour, A., Samsudin, T., \& Abdullah, W. A. T. (2009). An Application of three Dimensional electrical resistivity imaging for the detection of undergrouand wastewater system. Studia Geophysica et Geodaetica, 53(2009), 389-402.

3. Nirarita, C. H. E. (1996). Ekosistem Lahan Basah di Indonesia. Bogor: Programme.

4. Syech, R., Juandi, M., \& Edizar, M. (2014). Menentukan Lapisan Akuifer DAS (Daerah Aliran Sungai) Siak dengan Membandingkan Hasil Ukur Metode Geolistrik Resistivitas Konfigurasi Wenner dan Konfigurasi Schlumberger. Komunikasi Fisika Indonesia, 11(9), 601611.

5. Zahro, F., Usman, F., \& Wardhani, D. K. (2011). Arah Fungsi Lahan Berdasarkan Pendekatan Konservasi Tanah. Jurnal Tata Kota dan Daerah, 3(1), 33-38.

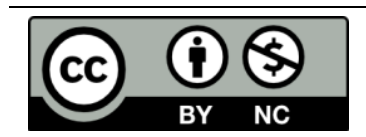

Artikel ini menggunakan lisensi Creative Commons Attribution 4.0 International License 